\title{
CURRENT ACCOUNT DEFICIT AND ITS CAUSES IN TURKEY
}

\section{Murat ÇAK}

Department of Public Finance, Faculty of Economics, Istanbul University, Istanbul, Turkey E-mail: cak@istanbul.edu.tr

Received December 14th, 2014; revised January 12nd, 2015

Copyright (C) 2015 Murat Cak. This is an open access article distributed under the Eurasian Academy of Sciences License, which permits unrestricted use, distribution, and reproduction in any medium, provided the original work is properly cited.

\begin{abstract}
Over the past decade the Turkish economy has witnessed many notable achievements. Foremost among these, of course, has been the sharp reduction in the rate of inflation, falling from 3-digit to single-digit figures comes from. Similar success stories include uninterrupted economic growth and record-breaking export levels, etc., can be mentioned during this period. Recently, however, especially during the last five years, international organizations influential in global economic development such as the IMF, OECD, and IBDR have repeatedly drawn attention to the fragility of Turkey's current account balance Many leading economists in Turkey along with the Central Bank have also started making statements such that "the current account deficit contains important risks, and measures need to be taken immediately." For these reasons, our study aims to describe why the current account deficit is so important and to identify the causative factors.
\end{abstract}

Keywords: Current Account Balance, Savings, Economic Growth, Foreign Trade, Economy of Turkey

JEL: E63, F32, F41, H62

\section{ÖZET}

Son 10 yılda Türkiye Ekonomisi pek çok hatırı sayılır başarıya tanıklık ettii. Bunların başında elbette ki enflasyonun 3 haneli sayılardan tek haneli rakamlara indirilmesi gelmekte. Üst üste alınan kesintisiz büyüme rakamlarından, ihracatta kırılan rekorlara kadlar pek çok benzer başarı öyküsünden bahsedilebilir. Ancak özellikle son beş yıldır, ekonomi alanında söz sahibi OECD, IMF, Dünya Bankası gibi uluslararası kuruluşlar, Türkiye'nin cari işlemler dengesinin vermiş olduğu açığa her firsatta dikkat çekmekteler. Türkiye içerisinde de önde gelen birçok ekonomistle birlikte Merkez Bankası 'da "Cari açık büyük risk içeriyor ve tedbir alınması gerekir" şeklinde açıklamalar yapmaya başlamış durumda. Bu gibi nedenlerle çalışmamızda cari açığın, neden bu denli önem arz ettiğini ve cari açığa hangi faktörlerin sebep olduğunu tanımlamaya çalıştık.

Anahtar Kelimeler: Cari işlemler Dengesi, Tasarruflar, Ekonomik Büyüme, Dış Ticaret, Türkiye Ekonomisi 


\section{Introduction}

As known, foreign economic relations of a country between other countries have been accounted and monitored on the basis of balance of payments of a country. On the other words, records of economic transactions between residents, and foreigners including institutions, are located in balance of payments (Seyidoğlu, 2001: 385). Current account balance is also a part of balance of payments. Current account balance contains several sub-accounts such as balance of goods, balance of services, balance of income, etc.

Turkey has had a serious deficit in its current account balance for years. After the 1980, as Turkey's economy became more open to international commerce, its current account deficit has steadily increased. Surely the various causes for this situation range from foreign trade to real exchange rate policy. After a brief description of the general condition of the Turkish economy, this paper will discuss the reasons responsible for the country's current account deficit.

Turkey made her economic policies to spur export after decisions taken in 1980. Incentives towards exports have been extended in every area such as tax exemptions, land donations, base price applications, etc. As a result of these implementations, foreign trade volume started to increase rigorously. On the other hand, since the prevailing structure of domestic savings discouraged economic growth, Turkey turned to foreign funding, adopting high interest rates along with low exchange rates as an integral part of economic policy. As a result, the flow of foreign funds into Turkey accelerated and within a short period of time this abundance of foreign exchange resulted in the appreciation of the Turkish lira. This, in turn, led to a drop in the price of imported goods and services, with the result that Turkey lost her export price advantage. (Kepenek, Yentürk, 2001).

Due to high domestic interest rates, banks preferred to purchase treasury bills and government bonds instead of financing investments in order to provide sustainability in budget deficit (Evgin, 1994). Ultimately, Turkish economy transformed into a structure that constantly sustained by short term foreign debts along with inflationary environment caused by domestic demand pressure. Deterioration in the economic structure had been continued to gain momentum in 1990s. Deficits in foreign trade and balance of payments hit a peak in 1993 at a level of 14.1 billion USD and 6.8 USD in a sequence (Boratav, Akyüz; 2002). However, due to the economic crisis that hit in 1994, the current account experienced a surplus that year due to currency devaluation, accompanied by a decrease in the volume of foreign trade. This 1994 economic crisis was one of the results of implemented public borrowing policy. Frequent exploitation of Central Bank resources also had a deleterious impact on 
price stability. As a consequence of these policies, IMF programs were frequently referenced (Şahin, 2002).

At the beginning of the millennium, two important, successive economic crises occurred. After the second of these, monetary and exchange rate policies that were previously imposed by the IMF were abandoned, and floating exchange rate regime was adopted by the government (Bulut, 2006). As a result of economic crisis, current account balance of Turkey again had a surplus in 2001 after 1994. The main objective of the new economic program proposed by the IMF was to curb the higher inflation rate. It was paid attention in disciplining public finance, especially after 2005. Applied monetary and exchange rate policies have been successful in fighting inflation so far. However, current account deficits have continued growing. The process of steady economic growth began in 2002 and continued for 27 successive quarters in a row. In this period, a large part of the increase in external debt stock was caused by private sector borrowing. Global economic crises that started in 2007, impacted Turkey's economy from the middle of 2008. While the increase in foreign trade volume continued until the last quarter of 2008, economic growth halted and budget revenues experienced a decline (YER, 2008).

The sharp drop in exports that began in 2009 stemmed from a decline in external demand. Turkish economy contracted by -4.7 percent and unemployment had risen to 14 per cent level in 2009 (YER, 2010). Due to these developments, the same year the current account deficit declined significantly. Related data from 1994, 2001, and 2009 show that the current account deficit had decreased or it had transformed into a current account surplus during the periods of economic crisis. This situation demonstrated the dependency of Turkey's economic growth on foreign trade, especially imports.

Table 1: Growth Rates, and the Current Account Deficit to GDP Ratio 1990-2012

\begin{tabular}{|c|c|c|c|c|c|}
\hline Years & GDP(\%) & $\begin{array}{l}\text { Cur. Acc. } \\
\text { Def/GDP }\end{array}$ & Years & GDP(\%) & $\begin{array}{l}\text { Cur. Acc. } \\
\text { Def/GDP }\end{array}$ \\
\hline $\mathbf{1 9 9 0}$ & 9,3 & -1.7 & $\mathbf{2 0 0 2}$ & 6,2 & -0.9 \\
\hline $\mathbf{1 9 9 1}$ & 0.7 & -0.1 & $\mathbf{2 0 0 3}$ & 5,3 & -3.4 \\
\hline $\mathbf{1 9 9 2}$ & 5,0 & -0.6 & $\mathbf{2 0 0 4}$ & 9,4 & -5.2 \\
\hline $\mathbf{1 9 9 3}$ & 7,7 & -3.5 & $\mathbf{2 0 0 5}$ & 8,4 & -6.1 \\
\hline $\mathbf{1 9 9 4}$ & -4.7 & 1,9 & $\mathbf{2 0 0 6}$ & 6,9 & -8.0 \\
\hline $\mathbf{1 9 9 5}$ & 7,9 & -1.3 & $\mathbf{2 0 0 7}$ & 4,7 & -5.9 \\
\hline $\mathbf{1 9 9 6}$ & 7,4 & -1.3 & $\mathbf{2 0 0 8}$ & 0.7 & -5.7 \\
\hline $\mathbf{1 9 9 7}$ & 7,6 & -1.3 & $\mathbf{2 0 0 9}$ & -4.8 & -1.9 \\
\hline $\mathbf{1 9 9 8}$ & 2,3 & -0.7 & $\mathbf{2 0 1 0}$ & 9,2 & -6.6 \\
\hline $\mathbf{1 9 9 9}$ & -3.4 & -0.7 & $\mathbf{2 0 1 1}$ & 8,5 & -10.1 \\
\hline $\mathbf{2 0 0 0}$ & 6,8 & -4.8 & $\mathbf{2 0 1 2}$ & 2,2 & $-6,2$ \\
\hline $\mathbf{2 0 0 1}$ & -5.7 & 2,2 & \multicolumn{3}{|l}{} \\
\cline { 1 - 4 } & & & &
\end{tabular}

Source: CBRT, TSI. 
Turkey's economy experienced a rapid recovery in 2010 and 2011, with the economic growth rate during those two years averaging 8.8\%. (YER, 2012). On the other hand, current account deficit broke the historical record, especially in 2011: the deficit reached the percent 10,1 of the GDP. After that peak, the government took some short term demand curbing precautions including credit card installments limitations in selected expenditures. Along with such limitations, in 2013 the government also passed new legislation associated with private pension plans in order to induce savings. Under this law, the state will add an extra TL 25 to every TL 100 deprosited in the private pension system, creating additional savings for citizens. Such measures taken to restrict demand have led to an improvement in the current account balance. This improvement, however, has resulted in a significant setback in economic growth. In the light of these findings, it seems that unless Turkey's economy changes the structure of production in a way that is less dependent on imports-especially intermediate goods and raw materials - it will continue to prefer between economic growth and the current account deficit.

\section{The Causes of the Current Account Deficit in Turkey}

The last ten years the economy has performed many firsts. Foremost among these, of course, inflation of 3-digit number to be reduced to single-digit figures comes from. We can mention about many similar success stories such as consecutive experienced uninterrupted economic growth figures, broken the records in exports, etc. However, especially in the last five years, organizations have a voice in the field of economics such as IMF, OECD, IBDR are dealing with the fragility of current account balance of Turkey at every opportunity. Many leading economists in Turkey along with the Central Bank have also started making statements such that "the current account deficit contains important risks, and measures need to be taken immediately."

For these reasons, in our study we try to describe why current account deficit is so important, and what the factors that cause current account deficit are.

\section{The lack of Domestic Savings and Budget Deficits}

A country's total amount of savings consists of the sum total of savings of private companies and households, as well as public sector savings. As we look at the tendency of the world savings, it is observed that there are serious savings surpluses in some countries such as China, Germany, Japan, Russia, Norway, Switzerland, etc. Countries such as these that have savings surpluses help to finance other nations that do not. 
There are two vital elements like income and interest rates that determine private savings. On the other hand, the most important factor determining public savings is budget deficit. As tax rates increase in order to promote public savings, it reduces private savings (Cooper, 2008, 93).

When we look at the trend of savings in Turkey, a continuous downward trend in the GDP share of savings can be observed (Table 2). Considering that in 2012 the average saving rate worldwide was $23.9 \%$, it is obvious that Turkey's savings rate is far below average. It should also be noted that Turkey's total fixed capital investment ratio is below the related ratio of the $23.6 \%$ world average (WEO, 2013). Despite this, the sum of total fixed capital investments are realized on total domestic savings. In this case, foreign savings are thought to be effective. The high level of domestic savings helps the savings used to finance high economic growth and it means that the country is less vulnerable against negative economic developments in worldwide.

Table 2: Domestic Savings and Fixed Capital Investment to GDP ratio, 1990-2012

\begin{tabular}{|c|c|c|c|c|c|c|}
\hline & 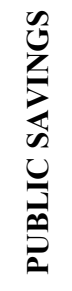 & 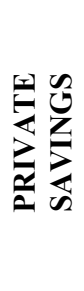 & 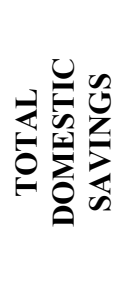 & 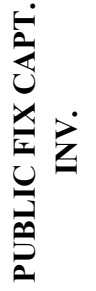 & 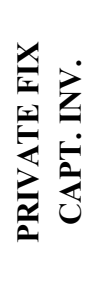 & 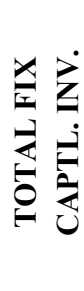 \\
\hline 1990 & 2,6 & 22,1 & 24,7 & 5,2 & 16 & 21,2 \\
\hline 1991 & 0,7 & 23,9 & 24,6 & 5,6 & 16,5 & 22,1 \\
\hline 1992 & $-0,6$ & 24,6 & 24 & 5,5 & 16,4 & 21,9 \\
\hline 1993 & $-0,7$ & 25,8 & 25,1 & 5,4 & 19,2 & 24,6 \\
\hline 1994 & $-0,1$ & 25 & 24,9 & 3,7 & 19,1 & 22,8 \\
\hline 1995 & $-0,1$ & 24,6 & 24,6 & 3,1 & 19,6 & 22,8 \\
\hline 1996 & $-1,1$ & 23,4 & 22,3 & 3,8 & 20 & 23,8 \\
\hline 1997 & 0,8 & 22,6 & 23,4 & 4,6 & 20,5 & 25,1 \\
\hline 1998 & $-1,4$ & 25,7 & 24,3 & 4,8 & 18,3 & 23,1 \\
\hline 1999 & -5 & 25,1 & 20,1 & 4,9 & 14,4 & 19,3 \\
\hline 2000 & $-3,4$ & 21,8 & 18,4 & 5,2 & 15,7 & 20,8 \\
\hline 2001 & $-7,1$ & 25,5 & 18,4 & 4,7 & 11,7 & 16,4 \\
\hline 2002 & $-4,8$ & 23,4 & 18,6 & 4,9 & 12,2 & 17,1 \\
\hline 2003 & $-4,1$ & 19,6 & 15,5 & 3,8 & 13,6 & 17,4 \\
\hline 2004 & -1 & 16,9 & 16 & 3,2 & 17,5 & 20,7 \\
\hline 2005 & 2,8 & 13,1 & 15,9 & 3,8 & 17,6 & 21,4 \\
\hline 2006 & 4,2 & 12,4 & 16,6 & 3,8 & 18,9 & 22,6 \\
\hline 2007 & 2,4 & 13,1 & 15,5 & 3,9 & 17,9 & 21,8 \\
\hline 2008 & 1,7 & 15,1 & 16,8 & 4,1 & 16,1 & 20,2 \\
\hline 2009 & $-0,9$ & 14,1 & 13,2 & 4,1 & 13,1 & 17,2 \\
\hline 2010 & 1,6 & 12,3 & 13,9 & 4,3 & 14,8 & 19,1 \\
\hline 2011 & 2,9 & 10,5 & 13,3 & - & - & - \\
\hline 2012 & 2,1 & 13 & 15,1 & - & - & - \\
\hline
\end{tabular}

Source: Republic of Turkey Ministry of Development 
When we turn back to Turkey, it is observed that personal income and interest rates level are less. This circumstance reduces the motivation to make savings. According to official figures, 5.5 million people make a living under the conditions of minimum wage in Turkey. Considering the level of the minimum wage which is TL 846 or USD 388, it is understood that setting goals about private savings are so difficult.

In fact, wage policy is not the only reason that reduces savings rates. The scarcity of the projects that create new employment areas are also an important element declining in savings rates. It is essential to expand the workforce, especially for women and those currently unemployed. This provides to expand savings base in the country. Depending on the abundance of capital in the world, reducing the cost of access to credit has increased to demand for credit especially for the last ten years. This increase in loans was reflected in consumption and imports, and encouraged consumption of the individuals. Broadening the base of credit has also accelerated the increase in asset prices. Excessive consumption has distorted in community's composition of consumption - savings, in favor of consumption.

Since 1973, years of uninterrupted budget deficits in Turkey have led to a decline in public savings as well. Coinage had been preferred in financing of the budget deficit until the 1990s. Since then, however, domestic and foreign borrowing has been relied upon extensively, motivated in large part by the inflationary pressures caused by the printing of currency (Demir 2001, 57). Banks that should have directed the country's savings into productive investments via loans instead turned to the state's debt paper due to the high returns. Persistent foreign debts arising from ongoing budget deficits led to corrosion in foreign exchange earnings obtained through foreign trade. This has strengthened the current account deficits.

\section{Foreign Trade Deficits and Exchange Rate Policy}

Foreign trade deficits are the main reason for current account deficits. The reason why the current account balance has deficit is the increase of imports far greater than exports. As we have evaluated the import and export developments in recent years, we can see that exports exceeded the limit of USD 100 billion for the first time in 2007. Although rising of exports up to USD 132 billion in 2008, it declined to USD 102 billion in 2009. 
Table 3: Composition of Current Account Balance

\begin{tabular}{|c|c|c|c|c|c|c|}
\hline & $\mathbf{2 0 0 7}$ & $\mathbf{2 0 0 8}$ & $\mathbf{2 0 0 9}$ & $\mathbf{2 0 1 0}$ & $\mathbf{2 0 1 1}$ & $\mathbf{2 0 1 2}$ \\
\hline $\begin{array}{c}\text { Curr. Acc. } \\
\text { Balance }\end{array}$ & -38.434 & -41.524 & -13.370 & -46.643 & -77.141 & -47.476 \\
\hline $\begin{array}{c}\text { For. Trade } \\
\text { Balance }\end{array}$ & -46852 & -53.021 & -24.850 & -56.445 & -89.092 & -65.712 \\
\hline $\begin{array}{c}\text { Services } \\
\text { Balance }\end{array}$ & 13.283 & 17.748 & 17.316 & 16.658 & 20.130 & 23.545 \\
\hline $\begin{array}{c}\text { Income } \\
\text { Balance }\end{array}$ & -7.108 & -8.364 & -8.191 & -7.215 & -7.841 & -6.676 \\
\hline $\begin{array}{c}\text { Current } \\
\text { Transfers }\end{array}$ & 2.243 & 2.113 & 2.355 & 1.523 & 1.758 & 1.367 \\
\hline
\end{tabular}

Source: CBRT

The main reason for this decline in 2009 was the global economic crisis that began in the U.S. and by mid-2008 was being felt world-wide. Turkey's foreign trade with African Countries has been a slight surplus since 2008. In addition to this longer than eight years, foreign trade with Near and Middle Eastern Countries has also a little surplus. On the other hand, according to 2011 figures in foreign trade with Commonwealth of Independent States, the ratio of exports to imports was $34 \%$.

When considering foreign trade data in terms of main commodity groups, it is understood that the weighted share of intermediate goods has been maintained, both in exports and imports. The portion of intermediate goods in total imports was approximately $70.8 \%$, while their share in exports was about 48.7\%, according to 2011 figures. The ratio of total imports of intermediate goods, except energy products was $48,5 \%$ in 2012. Intensive use of imported inputs, even in manufacture of the exported goods, causes this situation.

As the products that led to foreign trade deficit most have been listed from largest to smallest, it has been observed that mineral fuels, mineral oils, machinery and mechanical devices, iron and steel, electrical machinery and apparatus, plastic and plastic products have located in the first rows, respectively.

Ultimately, Turkey should accelerate the pace of work in products group which can be produced at lower level as primarily such as flat iron and steel, coal, medicine, paper, organic and inorganic chemical products etc., in order to alleviate current account deficit. In imported products group that completely formed according to the preferences of domestic consumers, and depending on factors such as the make, model, image, etc., Turkey should promote the introduction of domestic products that can be substituted for similar items now being imported.

One factor affecting the level of imports of goods and services in the economy is the real exchange rate. Exchange rate is the price of a reserve currency in terms of the currency of the country. The real exchange rate is a measure that compares the rates of the TL price of imported goods to TL price of domestic goods. When the real exchange rate increases, TL price of imported goods have escalation compared to TL the price of domestic goods. As a result, demand for imported goods will be reduced 
gradually. Reversely, when the real exchange rate decreases, TL price of imported goods will be cheaper compared to the TL price of domestic goods, and thus imports are going to be raised.

For example, if the U.S. Dollar rate of TL is 2.00 / $\$$, the exporters will find the price of any commodity that has a value of 1000 TL by calculating 1000/2.00. When the USD / TL parity is analyzed, all in the context of above mentioned disclosure, it has been observed that Turkish lira against the U.S. dollar has been more valuable than it should be from 2006 until the last days of 2013. This case inferred from the data of the Central Bank's 2003 CPI-based real exchange rate index. According to Central Bank's data, for example, Turkish lira was more valuable by 19,6 per cent against the US dollar in May 2013. The ratio was around 30-31 \% in October-November 2010. However, due to political developments occurred in December 2013, this ratio associated with TL/USD is regressed by 6 per cent. Thus, exchange rate has become more convenient for export.

Graphic 1: CPI Based Real Effective Exchange Rate 2003=100

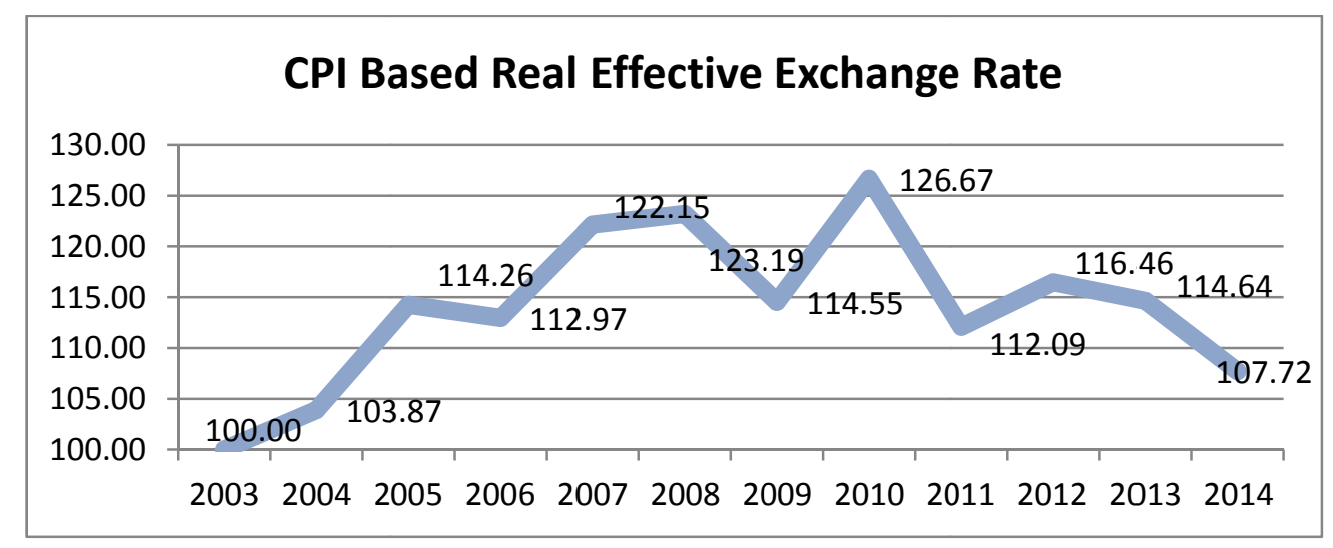

The most effective factor causing upward in the real exchange rate is foreign currency abundance due to high interest rates. For instance, although the real interest returns in Turkey has been 91,3 percent for the last ten years cumulatively, it has been $-4,2$ percent in the US, and 1,1 per cent in Euro areas in the same period. If the foreign exchange is used only in foreign trade transactions, the exchange rate is determined by exporters' supply of foreign exchange and importers' demand for foreign exchange. Under this condition, the real exchange rate does not deviate considerably from its equilibrium value. In other words, if the foreign exchange is used only in foreign trade transactions, foreign exchange rate moves to balance to the foreign trade. However, this automatic balancing mechanism does not work when the foreign exchange is used to invest in abroad or to transfer of wealth. Foreign savings that transferred to Turkey to make profit in the form interest returns have broken the link between the external value and the domestic determinants of purchasing power of Turkish Lira. If the real exchange rate is determined as it should be, and is not suppressed for declining in its value, the exports will increase due to price competition, and the current account deficit will fall. 


\section{Economic Growth}

Economic growth and the current account balance move adversely in the Turkish economy. In the years when economic growth has been high, the current account balance has run a deficit; during periods when the economy shrinks or during years of economic crisis, the current account balance has either shown a surplus or there has been a sharp decline in the current account deficit. For example, when economic growth turned negative in 1994 and 2001, the current account balances showed surpluses. In 1999 and 2009-years also characterized by negative growth-there was a marked decline in the current account deficit. In that respect, Turkish economy has a structure that growing with inflows of external resources and shrinking with outflows external resources. Importweighted achieved economic growth, both far from being sustainability and it makes the domestic economy more fragile to negative external economic developments. Due to the fact that many final export products are manufactured using imported inputs, domestic production is not expanded countrywide. As a result, potential new employment opportunities are not being developed and the resulting lack of economic growth makes it difficult to reduce unemployment figures.

Table 4: Unemployment rates (\%)

\begin{tabular}{|c|c|c|c|c|c|c|c|}
\hline $\mathbf{1 9 9 0}$ & 8,5 & $\mathbf{1 9 9 6}$ & $\mathbf{7 , 1}$ & $\mathbf{2 0 0 2}$ & 10,8 & $\mathbf{2 0 0 8}$ & 11 \\
\hline $\mathbf{1 9 9 1}$ & 8,7 & $\mathbf{1 9 9 7}$ & 7,3 & $\mathbf{2 0 0 3}$ & 11 & $\mathbf{2 0 0 9}$ & 14 \\
\hline $\mathbf{1 9 9 2}$ & 9 & $\mathbf{1 9 9 8}$ & 7,4 & $\mathbf{2 0 0 4}$ & 10,8 & $\mathbf{2 0 1 0}$ & 11,9 \\
\hline $\mathbf{1 9 9 3}$ & 9,4 & $\mathbf{1 9 9 9}$ & 8,2 & $\mathbf{2 0 0 5}$ & 10,6 & $\mathbf{2 0 1 1}$ & 9,8 \\
\hline $\mathbf{1 9 9 4}$ & 9,1 & $\mathbf{2 0 0 0}$ & 7 & $\mathbf{2 0 0 6}$ & 10,2 & $\mathbf{2 0 1 2}$ & 9,2 \\
\hline $\mathbf{1 9 9 5}$ & 8,1 & $\mathbf{2 0 0 1}$ & 8,9 & $\mathbf{2 0 0 7}$ & 10,3 & $\mathbf{2 0 1 3}$ & 9,9 \\
\hline
\end{tabular}

Source: Republic of Turkey Ministry of Development

High growth rates during the years of 2000s have been achieved by high rated current account deficits. While the average annual economic growth has been 5,45 percent between the years 20022011, the average annual current account deficit to GNP ratio has been $-5.3 \%$ in the same period.

Thus, economic growth should be achieved by the internal dynamics of the country, and structure of the production must be freed from import dependency.

On the other hand until above mentioned structural transformation in production would be achieved, high rate economic growth should be continued with measures to make financing of current account deficit less fragile. Short-term ones of these measures are particularly related to foreign policy between the EU and Turkey. Any improvement in relations with the EU will make significant contributions in attracting foreign direct investments into Turkey. As you remember, in the immediate aftermath of 2005, which was the beginning of the negotiations with the EU, Turkey had reached a record level of foreign direct investment inflows in 2006. This concreate example 
proves that Turkish Economy reacts quickly and positively to the favorable steps taken in the political and the legal fields. In order to finance current account deficit that is currently financed mainly by the surplus in portfolio investments, with the foreign direct investment inflows, it should be paid attention to the EU policy of Turkey.

\section{Conclusions}

Problems with the current account balance are the cumulative result of the economic policies implemented for years. Short-term measures aimed at solving the problem can bring temporary relief but will not be a permanent fix. Indeed, with the measures taken aftermath 2011 that was the current account deficit peaked, economic growth was slowed in a controlled manner by narrowing the demand, as a result of this current account deficit in 2012 decreased compared to the previous year. However, in 2013 economic growth began to regain momentum and the deficit in the current account balance started to grow once again. At the end of the 2013 the government took some short term demand curbing precautions including credit card installments limitations in selected expenditures such as food, fuel, automobile, etc. With these measures were thought that the demand can be shortened more effectively especially for imported goods. Taken measures to restrict demand, have led to an improvement in the current account balance. However this improvement has resulted in a significant setback of economic growth.

Instead of curbing demand, Turkey should accelerate the pace of work in products group which can be produced at lower level as primarily such as flat iron and steel, coal, medicine, paper, organic and inorganic chemical products etc., in order to alleviate current account deficit. In addition, the structure of production in Turkey's economy should be altered to lessen her dependence on imports, especially in intermediate goods and raw materials. The real exchange rate is also determined as it should be. As a result of this, exports will increase due to price competition, and the current account deficit will fall. 


\section{REFERENCES}

- $\quad$ Akyüz, Y. and Boratav, K., The Making of the Turkish Crisis, UNCTAD, Cenevre. http://www.bagimsizsosyalbilimciler.org/yazilar/AkyuzBoratav.htm, 2002.

- Bulut, C., Ekonomik Yapı ve Politika Analizi, Türkiye Ekonomisi Performans Değerlendirmesi, İstanbul, Der Yayınları, 2006.

- Cooper, Richard N., Global Imbalances: Globalization, Demography, and Sustainability, Journal of Economic Perspectives, Volume 22, Number 3, 2008.

- Çak, M., Türkiye'de Cari Açık, Beşir Kitabevi, İstanbul, 2013.

- Demir Ö., Türkiye'de Kamu Açıları ve ArtışSebepleri, DEÜ İ.İ.B.F. Dergisi, Cilt: 16, Say1: 2, 2001.

- Evgin, T., 90’lı Yıllarda Bütçe ve Bütçe Açı̆̆ının Finansmanı, Ekonomik Yaklaşım, Cilt 5, Sayı 13, 1994.

- Kepenek, Y., Yentürk, N., Türkiye Ekonomisi, 12. Basım, Remzi Kitabevi, İstanbul, 2001.

- Seyidoğlu H., Uluslararası İktisat, Teori, Politika ve Uygulama, Geliştirilmiş 14. Baskı, Güzem Yayınları, İstanbul, 2001

- Şahin, H., Türkiye Ekonomisi Tarihsel Gelişimi-Bugünkü Durumu, 7. Bask1, Ezgi Kitabevi, Bursa, 2002.

- Yıılık Ekonomik Rapor(YER), Maliye Bakanlığı Strateji Geliştirme Başkanlığı, Ankara, 2008.

- Yıllık Ekonomik Rapor(YER), Maliye Bakanlığı Strateji Geliştirme Başkanlığı, Ankara, 2010.

- Yıllık Ekonomik Rapor(YER), Maliye Bakanlığı Strateji Geliştirme Başkanlığı, Ankara, 2012.

- World Economic Outlook (WEO), IMF, Washington DC, 2013. 